Vol. 1 No. 02 Hal. 28 - 35

September 2018

\title{
Melirik Urgensitas Spiritualitas Pada Masyarakat Modern dan Kaitanya Dengan Pendidikan Dalam Kehidupan
}

\author{
Abdul Hakim Siregar \\ Dosen PNS Kopertis Wilayah I Sumatera Utara DPK UISU \\ abdulhakimsiregar@fkip.uisu.ac.id
}

\begin{abstract}
ABSTRAK
Allah mengingatkan manusia bahwa : Kamu akan menyaksikan manusia itu betapa hebatnya mereka mengejar kehidupan dunia, malah ada diiantara manusia itu menyatakan bahwa dunia inilah segalanya (tak ada Tuhan kalau tak ada dunia ini, padahal dunia ini ada kerana ada Tuhan.), mereka memaksakan dirinya supaya hidup seribu tahun, padahal panjangnya umum seseorang bukan jaminan masuk sorga.- Alquran 2/96. Dengan isyarat ini, perlu rasanaya melirik sejenak bagaimana sebenarnya urgensitas spiritualitas pada masyarakat modern, dan dengan demikian akan diperoleh manfaat agama sebagai alternatif menenangkan jiwa dan akan menghindarkan diri dari sifat semena-,ena dalam hidup ini. Spiritualitas, merupakan sikap manusia yang memiliki fundamentalitas hidup dan konsisten, yang tidak sependapat dengan sikap tersebut, apapun alasannya, dianggap melanggar hak-hak kemajuan hidup manusia dan mereka yang melanggar hakhak manusia merupakan beban mental membuat ketidak nyamanan pergaulan, akan terbuka kemungkinan saling salah menyalahkan, perdebatan yang bisa membawa sifat iri hati dan seterusnya. Kehadiran spiritualisme dalam kehidupan manusia modern tidak terlepas dari upaya penyucian jiwa (tazkiyatun nafs), dan penjernihan hati ( tashfiyatul qalbi) yang bertujuan untuk menerima kahadiran Tuhan yang Maha pencipta alam semesta dalam semua aktivitasnya dan menandakan keterbatasan manusia dalam sesuatu hal
\end{abstract}

\section{PENDAHULUAN.}

Bila ada peluang sedikit waktu dalam menganalisa , memperhatikan bagaimana kehidupan, dan perilaku manusia modern, hidup dalam rentang waktu dua puluh empat jam tidak lebih dari itu, maka kita akan mendapatkan satu simpulan bahwa seolah-olah mereka tidak akan mati. Karena pada umumnya manusia atau masyarakat modern itu mungkin telah kehilangan keseimbangan akibat berkilaunya material yang dikejarnya, sayangnya, apa yang dikejarnya itu hanya bayang-bayang tetap tidak memuaskankan dirinya, keheningan malam hampir tak dinikmatinya. Begitulah hidup sehariannya. Allah mengingatkan manusia bahwa : Kamu akan menyaksikan manusia itu betapa hebatnya mereka mengejar kehidupan dunia, malah ada diiantara manusia itu menyatakan bahwa dunia inilah segalanya (tak ada Tuhan kalau tak ada dunia ini, padahal dunia ini ada kerana ada Tuhan.) , mereka memaksakan dirinya supaya hidup seribu tahun, padahal panjangnya umum seseorang bukan jaminan masuk sorga.- Alquran 2/96. Dengan isyarat ini, perlu rasanaya melirik sejenak bagaimana sebenarnya urgensitas spiritualitas pada masyarakat modern, dan dengan demikian akan diperoleh manfaat agama sebagai alternatif menenangkan jiwa dan akan menghindarkan diri dari sifat semena-,ena dalam hidup ini.

A. Memahami Spiritualitas dan Modernitas.

-SPIRITUALITAS,

Secara etimologi, spiritualitas dan atau spiritualisme terambil dari kata" spirit" yaitu 
Abdul Hakim Siregar : Melirik Urgenitas Spiritualitas Pada Masyarakat Modern dan Kaitanya Dengan Pendidikan Dalam Kehidupan

kata yang berasal dari " spiritus" (latin), artinya roh, jiwa, sukma kesadaran diri, keberanian, wujud tak berbadan, nafas hidup, nyawa hidup" .Dalam Kamus Bahasa Indonesia, menyebut bahwa arti spiritualisme adalah yang bersifat kejiwaan, rohani, batin, mental dan moral. Akan halnya bahwa istilah spiritualisme ini disejajarkan dengan" ruhaniyah" (Arab), dan oleh Muhammad Husein Abdullah, dalam bukunya "Mafaahim Islamiyah" mendefinisikan bahwa ruhaniyah sebagai "idraku as-shilatu Billahi"(kesadaran hubungan dengan Allah). Dari makna tersebut di atas, dapat kita fahami bahwa spiritualisme adalah merupakan salah satu faham kerohanian yang berpandangan bahwa hakikat alam semsta ini adalah kesadaran yang immaterial. Tentu akan bertentangan dengan pandangan aliran atau faham materialisme yang mengasaskan perinsip, bahwa seisi alam semesta ini adalah materi belaka. Singkatnya bahwa spiritualisme adalah kehidupan yang dikendalikan dan dibimbing oleh ajaran agama tertentu sehingga harus selalu menyesuaikan diri dengan ketentuan agama yang diyakininya. Bagi orang awam bisa jadi sulit membedakan dalam memahami antara pengertian agama dan spiritualisme, sementara kaum spiritualisme juga seringkali berpijak dan mengacu pada ajaran agama. Fakta ini, kenyataan dalam pengamalan dilapangan kehidupan masyarakat, yang mana ajaran agama dan yang mana ajaran spiritual. Sehingga tidak jarang kemungkinan akan bercampur baur atau ada kekaburan pemahaman gerakan agama dan gerakan spiritual. Prof.Carrel (ilmuan Perancis), menyatakan : " sebelum kita melakukan sesuatu, kita harus menghilangkan penghalang pertumbuhan spiritual -demikian juga agama-(pen). Sebelum kita bergerak maju, kita harus melepaskan kebiasaan-kebiasaan dan prilaku jahat yang dapat melumpuhkan pertumbuhan spiritual. Namun, apa selanjutnya yang harus kita lakukan setelah penghalang itu tersingkir?. Kemudian setelah itu barulah kita mulai (usaha) pengembangan spiritual yang berkaitan dengan kecenderungan-kecenderungan fitrah hidup manusia. Memang, dalam setiap agama terkandung didalamnya spirit, daya, kekuatan, yang diyakini mampu membawa semangat dan ketegaran hidup bagi pemeluknya. Dan dengan spirit itu, seseorang akan dapat seoptimal mungkin beraktivitas dalam menghasilkan kebutuhan dirinya baik yang bersifat material maupun bersifat immaterial. Oleh karena itu spiritual terlihat urgensinya bagi masyarakat modern, atau dari sisi filsafat dan agama. Dari sisi filsafat, bahwa spiritualisme merupakan faham "aliran filasafat yang mengutamakan kerohanian; ia merupakan banyak perhatian pada ilmu-ilmu gaib..Juga dapat diartikan sebagai spirit, titik kulminasi jiwa atau roh, semangat,yang merupakan penggerak seseorang dalam melaksanakan kreativitas hidup. Namun, kadangkala, kurang diperhatikan dengan sebenarnya bahwa spirit itu adalah energi yang hidup dan aksi nyata, meskipun energi itu tidak terlihat dengan mata telanjang. Intraksi dengan spirit yang hidup itulah sesungguhnya yang disebut "spiritual" bersifat kejiwaan, rohani, batin ", Kekuatan spiritual ini adalah kekuatan, penggerak besar yang dapat menyelimuti dunia yang lebih bergairah. Manusia di saat ia merasa hanya fisik semata, maka ia ibarat robot tanpa rasa menikmati hidup yang kompleks. Kekuatan spiritual, (dunia ide).akan mampu menghadirkan rasa dalam kehidupan sehingga ia menjadi hidup dan lebih hidup lagi.

Diskusi tentang spiritualisme pada dasarnya menggerakkan pemikiran kearah faham, aliran ajaran tertentu yang sangat erat dengan pembicaraan kekuatan jiwa, rohani, batin, menghubungkannya manusia dengan Tuhan, tetapi tidak jarang terjadi pembahasan masuk keranah politik. Memamng politik itu salah satu cara menghasilkan sestu tujuan. Plato, membagi manusia kepada dua unsur, jasmani dan rohani. Klassifikasi ini didasarkan pada pengelompokan seluruh realitas kepada dua bagian, yaitu: bentuk reel (dunia realitas) dan bentuk abstrak (akhirat). Menurut Plato, dari dua klassifikasi ini unsur yang paling hakikat dan rumit pada manusia adalah unsur rohani (ide). "Ide bukan diartikan sebagai gagasan atau pemikiran, melainkan sebuah dunia reel yang bereksistensi.. Manusia akan 
Abdul Hakim Siregar : Melirik Urgenitas Spiritualitas Pada Masyarakat Modern dan Kaitanya Dengan Pendidikan Dalam Kehidupan

memperoleh kesempurnaan manakala rohaninya mampu melepaskan diri dari pengaruh jasmani. Yahya Jaya, menjelaskan bahwa :sungguhpun al-Ghazali membenarkan konsep manusia menurut Islam tersusun dari jasmani dan rohani, akan tetapi ia menekankan pengertian dan hakikat kejadian manusia itu dapat dilihat pada spiritualnya, rohani atau pada jiwanya. Manusia itu pada hakikatnya dapat dilihat dari jiwanya (akal). Jiwalah yang membedakan dengan makhluk-makhluk ciptaan Allaah. Dengan jiwa manusia dapat merasa, berpikir, berkemauan, dan berbuat lebih baik. Tegasnya jiwa/ akal itulah yang menjadi hakikat yang hakiki pada manusia karena sifatnya yang latif (lemah lembut), rabbani (pemilik), dan abadi sesudah mati. Dari sisi agama, bahwa spiritualisme dimaknakan sebagai suatu alairan atau kepercayaan yang memeliki energi (penggerak) yang kuat dan kokoh juga merupakan azas dalam suatu agama, karenanya spiritualisme berada diranah agama, yaitu kehidupan yang dikendalikan dan dibawah bimbingan agama. Manusia harus mengatur dimensi-dimensi wujud-Nya dalam berbagai arah sedemikian rupa sehingga dia mampu memenuhi semua kebutuhan material dan spiritualnya, hidup dengan terhormat mendasarkan kehidupannya pada rencana hidup yang tepat dan akurat. Salah satu pidato Prof. Eric Lincoln,(sosiologi agama di University Amerika), oleh Sayed Mujtaba Musawi Lari, mengutip pidato Prof. Eric mengenai topik: Dampak Islam di Amerka sebagai berikut: Dampak Islam terhadap Negro Amerika luar biasa. Sebelum mereka memeluk Islam, mereka hidup dalam kondisi kehidupan yang paling buruk, tetapi sekarang mereka menempati darajat kehidupan sosial ekonomi yang jauh lebih tinggi. Di kalangan keluarga-keluarga Islam Negro Amerika (Black Muslims) tak ditemui adanya penyimpangan penyimpangan prilaku kaum muda dan adanya kecanduan obat-obat terlarang, suatu fenomena yang membuat masyarakat Amerika panik. Bahkan pecandupecandu obat terlarang yang lalu, setelah mereka memeluk Islam, menerima latihan-latihan yang membuat mereka mampu melepaskan diri dari ketergantungan obat dan menjadi warga masyarakat yang sangat produkrif. Kaum Islam Negro Amerika sama sekali tidak pernah mendatangkan kesulitan terhadap orang lain. Hanya jika mereka diintimidasi atau diserang, mereka akan mempertahankan diri dengan segenap kekuatan yang ada pada mereka. Dan hal ini mereka selalu berhasil. Dr.Muhammad Hatta, bahwa soal agama banyak yang bisa dipecahkan dengan metoda ilmiah, tetapi agama yang berdasarkan kepada kepercayaan yang mutlak. Bagi kita muslim, percaya kepada ada-Nya (Allah) itulah pokok segala-galanya. Oleh Ruslani dalam bukunya Wawasan spiritual Timur dan Barat, memuat tentang spiritual dalam berbagai agama dan spiritual tanpa agama. Masingmasing memberi wawasan tersendiri mengenai spiritualitas dengan berangkat dari sejarah masing-masing kondisinya pada zaman itu

Demikian juga Hinnel,menyatakan bahwa dalam setiap agama tercantum perinsip-perinsip mencari kesejukan hidup dengan jalan spiritualitas dan ia membagi tingkatan spiritualitas kepada tiga tingkatan, yaitu: Pertama, spiritualitas sebagai pengalaman praktis, suatu konteks keagamaan yang dapat dilihat dari aspek IMAN. Kedua, spiritualitas sebagai pengajaran yang memancar keluar dari praktek pengalaman yang memandu kedisiplinan menuju kesempurnaan hidup. Ketiga .spiritualitas sebagai sistimatis, membandingkan pengalaman rohani dalam menelusuri jalan baru.Pada intinya, agama-agama di dunia tidak terlepas mengaitkan bahwa ketenteraman dan kenyaman hidup manusia bersumber pada agama yang dianutnya dan ini salah satu manfaat agama bagi manusia. Sebaliknya mereka yang meninggalkan ajaran agamanya akan berdampak negatif antara lain kesengsaraan dan kebuntuan hidup pada akhirnya mereka akan mencari jalan pintas. 
Abdul Hakim Siregar : Melirik Urgenitas Spiritualitas Pada Masyarakat Modern dan Kaitanya Dengan Pendidikan Dalam Kehidupan

\section{MODERNITAS}

Modernitas berasal dari "modern" yang berarti paham kemodrenan. Moderenisme adalah lawan dari kata fundamentalisme. Modernitas diartikan sebagai fase terkini sejarah dunia yang ditandai dengan percaya kepada sains, perencanaan, sekularisme, dan kemajuan. Modernitas dapat juga ditandai oleh keyakinan terhadap masa depan, bahwa ada sebuah tata dunia natural yang mungkin terjadi perubahan yang dihadapi masyarakat yang berbeda sebelumnya. Bila membicarakan modernitas dalam konteks pemikiran Islam, dapat difahami bahwa modernitas adalah merupakan istilah yang dimunculkan oleh masyarakat Barat terhadap masyarakat Islam, Terlepas dari asal usul tersebut, modernisme dianggap sebagai satu aliran atau paham yang muncul sebagai respon terhadap modernisasi dan westernisasi yang terjadi di dunia Islam, karena dunia Islam sudah lebih dahulu melaksanakan modernisasi dalam kehidupan sesuai dengan perinsip yang dianutnya: Laadina Liman Aqlalahu (tidak berlaku Islam kecuali bagi mereka yang berakal) artinya, bahwa ajaran Islam itu hanya ditujukan bagi mereka yang berakal dan seluruh ajaran Islam itu pasti rasional, tentu bagi mereka yang berpikirlah yang dapat memahami dan mendalami ajaran Islam. Kaum modernis berpandangan bahwa penyebab kemunduran umat Islam akibat kekakuam ulama dalam memahami Islam yang Kaffah dan rahmatan lil alamin. Maka untuk mengembalikan kejayaan umat Islam itu, kaum modernis menyerukan membuka pintu ijtihad seluas-luasnya. Maka dengan ijtihad, revitalisasi ajaran Islam (ekonomi, budaya, hukum dan politik) akan lebih dapat mewarnai kehidupan umat menuju kehidupan dunia modrn yang membuktikan Islam itu merupakan rahmat bagi seluuruh alam semesta.

\section{URGENSI SPIRITUALISME DALAM MASYARAKAT MODERN}

Kehadiran spiritualisme dalam kehidupan manusia modern tidak terlepas dari upaya Tazkiyatun Nafs.(penyucian jiwa) dan Tashfiyatul qalb ( penjernihan hati) guna untuk mendekatkan diri sedekat-dekatnya kepada Khaliqul 'Alam (pencipta alam semesta). Untuk mewujudkan semacam ini muncul perasaan kebimbangan, kebingungan sebagian masyarakat modrn, selain dilatarbelakangi berbagai keruwetan persoalan yang sulit ditembus nalar dan hati, seperti insiden fitnah al-Kubra (krisis politik, ekonomi dsb), juga dimotivasi oleh perilaku-perilaku (teror) yang menamakan gerakan Islam yang menakutkan, padahal gerakan itu belum ada kepastian apakah merupakan gerakan Islam yang sebenarnya. Karena dalam Islam sangat melarang membuat anarkis dan permusuhan. Spiritualisme, memamndang bahwa realitas kekinian (penucian dan penjernihan hati) merupakan gerakan vital kemanusiaan untuk menghilangkan penyakit masyarakat modern yang sebelumnya telah memberikan peluang pada dirinya menerima seluruh budaya yang datang tanpa memberikan sedikit filter, yang pada akhirnya mengalami kehancuran diri dan keluarganya. Kahancuran ini akibat menantang naluri hatinya dan pancaran Nur Ilahi yang seogianya naluri hati merupakan suluh dan modal utama yang harus menjadi sandaran hidup menenangkan jiwa. Malapetaka ini disebabkan kekosongan spiritualitas. Hilangnya kesadaran manusia tentang pentingnya spiritualisme ini akan berakibat fatal dalam mendekatkan diri kepada sang pencipta dan mengatur dirinya kepada sesama makhluk Tuhan untuk mendapatkan ridha-Nya. Dengan nihilnya spiritualisme pada diri seseorang Tuhanpun akan menhjauh tak terhingga. Bila ridha Tuhan tidak lagi menjadi pusat orientasi manusia, maka kualitas kehidupannya pun menjadi rendah dan tidak akan bermakna serta harta kekayaan tidak akan memberi kenikmatan malah akan menjadi beban pikiran dalam hidup karena gaya hidup yang glamour, kepedulian sesama hidup manusia 
Abdul Hakim Siregar : Melirik Urgenitas Spiritualitas Pada Masyarakat Modern dan Kaitanya Dengan Pendidikan Dalam Kehidupan

terlupakan. Ironisnya pada kondisi itu pulalah ia mati. Dalam pada itu kelihatan benar bahwa pentingnya spiritualisme diri dalam masyarakat modern. Spiritualisme akan dapat menjadi pengendali, pemelihara dan sebagai pelindung diri dalam kancah hidup modern.

\section{MODERITAS SEBAGAI KEBUTUHAN}

Setelah kita memahami pengertian modernitas, maka tentunya dalam setiap kurun waktu atau zaman, maka usaha modernisasi selalu ada dan berlanjut sepanjang manusia memiliki budaya dinamis. Setiap bangsa pada dasarnya akan terlibat dan terimbas dalam proses modernisasi. Tidak seorangpun dapat menghindarkan diri dari modernisasi kehidupan. Dalam hal ini Islam telah terbukti dalam kehidupannya antara lain aspek teologi, budaya dan politik. Artinya adanya perubahan atau modernisasi merupakan kewajaran yang harus dihadapi dengan pikiran tenang dan penuh kewaspadaan. Proses modernisasi tercatat dalam sejarah dimulai abad ke 2 SM, sampai abad ke 4 SM dimana saat itu kerajaan Romawi menentukan konstelasi pencaturan dunia. Banyak kerajaan disekitar laut Mediterania, kerajan Eropa Tengah dan Utara, secara sadar berusaha menyesuaikan diri dengan kerajaan Romawi baik dibidang politik, ekonomi dan budaya. Pada abad ke 4 SM sampai ke 10 SM, Kerajaan-kerajaan besar China dan India menentukan konstelasi dunia, banyak kerajaan Asi Timur dan di Asia Tenggara, termasuk kerajaan di Nusantara, terjadi berproses perubahan baik aspek ekonomi , budaya dan politik. Modernisasi di Inggris mulai pada abad ke $18 \mathrm{M}$, dimana saat itu terjadi revolusi industri yang disebut industrialisasi global, yang menghasilkan munculnya perkembangan ilmu dan teknologi, meluasnya teknologi komunikasi informasi membawa jarak dunia semakin dekat. Dan pada abad ke $20 \mathrm{M}$, konstelasi dunia ditentukan negara-negara besar dan memunculkan perubahan besar hampir tak bertepi, globalisasipun tak terhindarkan, negara yang tidak mengikuti globalisasi di cap sebagai negara tertinggal. Globalisasi menurut Akbar Shomad, dan Hastings Donnan " pada perinsipnya adalah mengacu pada perkembangan yang sangat cepat dalam teknologi komunikasi, transpormasi dan informasi yang membawa perubahan yang signifikan, sehingga menghilangkan identitas budaya sendiri." Padahal pada masa lalu beberapa bangsa meniru bangsa lain, namun tidak meninggalkan identitas bangsanya"

\section{RESPON AGAMA TERHADAP MODERNITAS.}

Salah satu trend ekspresif zaman post-modern adalah ditandainya pergolakan sosial yang cepat, namun disisi lain, manusia duhadapkan beribu-ribu krisis kemanusiaan, mulai dari krisis diri, alienasi, strees, keretakan institusi keluarga sampai beragam penyakit psikologis lainnya. Agama salah satu solusi untuk mencapai ketenangan, kemakmuran hidup dan diyakini mampu memberikan penyembuh penyakit psikologis yang melanda manusia dari penyakit keduniaan. Oleh D. Hendropuspito OC. Menjelaskan bahwa agama itu merupakan kekuatan non empiris yang dipercayainya dan di dayagunakannya untuk mencapai keselamatan diri dan masyarakat luas umumnya.

Modernisme yang menjadi pilihan untuk mencapai kemajuan banya orang atau negara, telah lama menimbulkan debat yang berkepanjangan. Dua pemikiran yang berhadapan adalah Marxian dan Webrian. Kubu Marxian melihat bahwa pembangunan budaya, agama, ekonomi dan politik memiliki keterkaitan dalam hidup manusia atau negara, karena pembangunan budaya, agama menentukan karakteristik sosial politik masyarakat. Namun agama belum tentu dapat memberikan kenyaman hidup manusia atau negara, demikian juga sebaliknya, akan tetapi faktor ekonomi dan agamalah yang dapat memakmurkan dan 
Abdul Hakim Siregar : Melirik Urgenitas Spiritualitas Pada Masyarakat Modern dan Kaitanya Dengan Pendidikan Dalam Kehidupan

memberi kenyamanan hidup manusia dan atau negara, terutama bila membicarakan modernisme. Maka tak heran kalau masyarakat dunia sangat cenderung bahkan memaksakan diri untuk masuk dan melaksanakan pola-pola modernisme, yang mereka anggap suatu perubahan yang cepat dan tepat dan tidak melihat lagi apek lainnya. Sementara pandangan pihak Webrian, bahwa kebudayaan (termasuk agama), akan dapat langsung membentuk kehidupan masyarakat atau negara yang relatif nyaman, karena agama membentuk manusia agar tidak semena-mena melanggar hak orang lain, atau kerakusan terhadap kebutuhan jasmani."dengan itu semua, maka manusia akan memperoleh kemenangan dalam meniti ujian-ujian hidup yang beraneka ragam bentuk dan warnanya. Walaupun keduanya terlihat berbeda pandang dalam mengimplementasikan nilai-nilai agama dalam kehidupan, namun pada dasarnya mereka mempunyai persamaan pendpat, bahwa perubahan sosial budaya termasuk agama dapat memahami perubahan anara pemikiran dan kebutuhan manuia , maka agama tidak akan bertentangan dengan modernisasi yang merupakan hajat orang banyak, selama mereka tidak menghilangkan nilai-nilai agama sebagai pondasi hidup manusia. Hasil suatu modernisasi dapat dipastikan akan mengalami konsekwensi sesuai dengan perkembangan masa atau zamannya.

Hubungan antara pembangunan ekonomi, sosial dan budaya begitu juga faktor teologi tetap menjadi bahan kajian Weber, sehingga melahirkan etika dalam kehidupan bermasyarakat, karena ia melihat bahwa di wilayah Eropa yang mempunyai perkembangan industrial kapital, akan berhadapan dengan etika masyarakat. Dengan memperhatikan kenyataan yang ada (reel), perlu juga diketahui nilai-nilai fundamental modernitas, yaitu: 1) Memiliki tanggung jawab dan sikap jujur. 2) Menunda kesenangan sesaat demi kesenangan yang abadi 3) Pemanfaatan waktu dan etos kerja, 4) Keyakinan bahwa keadilan dapat dirasakan, 5) Penghargaan yang tinggi pada ilmu pengetahuan, 6) Memiliki visi dan perencanaan yang tepat tentang masa depan, 7) Sangat menjunjung tinggi bakat dan kemampuan, serta memberikan penghargaan berdasarkan prestasi.

Melirik nilai-nilai fundamental tersebut di atas, tentu bagi Islam tidak asing lagi dan tujuh point tersebut sudah ada dalam ajaran Islam, Karenya Islam dapat menerima dan mendorong lahirnya modernisasi. Memang dalam tingkat pemikiran, muncul tiga corak pemikiran melihat modernisasi tersebut, yaitu; Pertama; menolak sepenuhnya modernitas, akibar anti Barat. Kedua, menerima sepenuhnya modernitas, yaitu mereka yang berpikir pro-sekularisasi (pemisahan antara agama dan politik) atau masalah-masalah keduniaan lainnya., westernisasi dan yang pro-terhadap kemajuan yang dicapai Barat. Ketiga .mereka yang bersikap kritis, melakukan filterasi, yaitu mereka yang tidak secara otomatis anti modernisasi atau anti Barat. Kelompok yang ketiga ini menganggap Barat tidak secara otomatis sebagai musuh, dan tidak pula menganggap Barat sebagai rule model yang hebat dan dipatuhi dalam segalanya dan harus ditiru. Kelompok ketiga ini dapat bersahabat dan kerjasama dengan Barat, namu tetap menampakkan sikap identitasnya.

\section{KESIMPULAN}

Bila dimaksud modernisasi adalah perubahan alat-alat atau fasilitas kebutuhan hidup manusia, maka modernitas dapat ditandai pada awalnya pada abad ke $18 \mathrm{M}$ dimana pada abad tersebut terjadi revolusi besar-besaran industri di Inggris. Industri yang menghasilkan kemajuan ilmu pengetahuan dan teknologi komunikasi yang telah dapat mempersempit dunia dan memproduksi peralatan yang cukup canggih untuk kebutuhan dan kelengkapan usaha manusia, antara lain kelengkapan alat-alat pertanian, komunikasi dan transportasi 
Abdul Hakim Siregar : Melirik Urgenitas Spiritualitas Pada Masyarakat Modern dan Kaitanya Dengan Pendidikan Dalam Kehidupan

dan kebutuhan manuaia lainnya. Bagi mereka yang mempasilitasi hidupnya dengan alatalat yang baru dan canggih/ up-todate sangat banyak membantu kelancaran pekerjaan mereka. Mereka yang memanfaatkan peralatan canggih ini disebut mayarakat modern, sebaliknya mereka sebut masyarakat berkembang. Spiritualitas, merupakan sikap manusia yang memiliki fundamentalitas hidup dan konsisten, yang tidak sependapat dengan sikap tersebut, apapun alasannya, dianggap melanggar hak-hak kemajuan hidup manusia dan mereka yang melanggar hak-hak manusia merupakan beban mental membuat ketidak nyamanan pergaulan, akan terbuka kemungkinan saling salah menyalahkan, perdebatan yang bisa membawa sifat iri hati dan seterusnya.

Kehadiran spiritualisme dalam kehidupan manusia modern tidak terlepas dari upaya penyucian jiwa (tazkiyatun nafs), dan penjernihan hati ( tashfiyatul qalbi) yang bertujuan untuk menerima kahadiran Tuhan yang Maha pencipta alam semesta dalam semua aktivitasnya dan menandakan keterbatasan manusia dalam sesuatu hal. Agama Islam menerima adanya perubahan atau modernitas fasilitas kehidupan sesuai nilai-nilai fundamentalitas yang dapat memudahkan pekerjaan yang selama ini dianggap berat, sulit. Maka bila modernitas itu dilaksanakan benar dan jujur sesuai nilai-nilai fundentalitas, maka eksistensi spiritualitas bagi masyarakat modern akan tetap eksis dan meguntungkan. Karena perinsip agama Islam dalam muamalah" bila ada jalan kemudahan kenapa dicari jalan kesulitan". .Maka dengan perinsip terbut manusia dapat menggunakan semaksimal mungkin menerima perubahan atau modrnitas.

Ada tiga pola pemikiran manusia terhadap moderniime, yaitu : pertama, menolak sepenuhnya modernitas. Sikap ini dilakukan mereka yang anti Barat. Kedua, Menerima sepenuhnya modernitas. Sikap ini yang dilakaukan mereka yang berpikir sekularisasi, Islamiphobi dan Islam liberalsasi. Yaitu mereka memisahakan ranah agama dan politik yang lebih jauh lagi mereka memisahkan agama dan dunia. Ketiga, mereka yang bersikap kritis, melakukan fiterasi, yaitu mereka yang tidak otomatis anti modernisasi atau anti Barat dan juga tidak menerima seluruhnya apa yang muncul dari Barat dianggap baik. Modernisasi dapat dilakukan dengan menggunakan pendekatan rasa rasio dan etika.

\section{DAFTAR PUSTAKA}

A.Qadri Azizy, Melawan Globalisasi, Pustaka Pelajar, 2003, Yogyakarta.

Akbar S. Ahmed , Post-Modernisme, Budaya Dan Harapan Bagi Islam, 1995, Mizan Bandun

AKH.Muwafik Saleh, Belajar Dengan Hati Nurani, 2011, Erlangga Jakarta.

Arifinsyah, Dialog Global Antara Agama, 2009 , Citapustaka Media Bandung..

Hasan Bakti Nasution, Filafat Umum, 2005, Citapustaka Media Bandung

Hendropuspito, OC, Sosiologi Agama , 1990, BPK. Gunung Mulia Jakarta

Hamdan Bakar Adz-Dzakiey, Psikologi Kenabiaan, 2012, Fajar Mulia Yogyakarta,

Kuntjaningrat, Kebudayaan Mentaliteit Dan Pemabangunan, 1976, Gramedia Jakarta, 
Abdul Hakim Siregar : Melirik Urgenitas Spiritualitas Pada Masyarakat Modern dan Kaitanya Dengan Pendidikan Dalam Kehidupan

Komaruddi Hidayat, Sidram Raja Midas, (artikel)

Kamus Besar Bahasa Indonesia, 1990 , Balai Pustaka Jakarta

Munir Baalbaki \& Rohil Baalbaki, Al-Maurid English-Erobic and Erobic English, Dictionary Daar Al-Ilmi lil Mayalin, 2002, Beirut.

Muhammad Husi Yakub, Mafaahim Islamiyah, 2000, Maktabah Shofa, Kairo

Muhammad Hatta, Ilmu dan Agama ,1980, Yayasan Idayu Jakarta

Ruslani, Wahana Spiritualisasi Timur Barat, terj. MQ.Sofyan, 2000, Qalam Yogyakarta

Syahrin Harahap, Islam Dan Modernitas Membangun Kesalehan Modrn, 2008 , Pranada Media Jakarta.

Sayed Muhtaba Lari, Ethic And Spiritual Growth, (Meraih Kesempurnaan Spiritual) Alih bahasa Asbin Muhammad, 1997 , Pustaka Hidayat Bandung 